\title{
Public Service Veterinarians Worldwide: a Quantitative Analysis
}

\author{
V. KOUBA \\ Former Chief, Animal Health Service, Food and Agriculture Organization \\ of the United Nations and Editor-in-Chief, FAO/WHO/OIE Animal Health Yearbook \\ Received November 30, 2004 \\ Accepted August 30, 2005
}

\begin{abstract}
Kouba V.: Public Service Veterinarians Worldwide: a Quantitative Analysis. Acta Vet. Brno 2005, 74: 455-461.

Historically the first global analysis of public service professional veterinary manpower (government veterinary officials at central and local levels) is based on available quantitative data reported by individual countries to international organizations. The analysis begins with a time series of reported number of public service veterinarians starting in $1983(65,930)$. In 2003 the number reached 209,888 representing $27.96 \%$ of all reported veterinarians in the world. Average ratio private/public veterinarians was 1.7850 and average ratio public/private veterinarians was 0.5602 . Global average values per public service veterinarian in 2000 were as follows: 31,522 inhabitants, 13,368 people depending for their livelihood on agriculture and 6,867 people economically active in agriculture; $680 \mathrm{~km}^{2}$ of land and $71 \mathrm{~km}^{2}$ of arable land; 6,923 cattle, 870 buffaloes, 313 horses, 5,421 sheep, 3,719 goats, 4,711 pigs and 74,581 chickens; 9,221 livestock units; slaughtered 1,445 cattle, 2,517 sheep, 1,024 goats and 6,026 pigs; production of $1,211 \mathrm{t}$ meat, $2,551 \mathrm{t}$ cow milk and $267 \mathrm{t}$ hen eggs; internationally traded 43 cattle, 83 sheep, 80 pigs, 2 horses, 3,910 chickens and $120 \mathrm{t}$ total meat. The analysis is complemented by the examples of the countries with the highest number of public service veterinarians, with the highest ratio private/public veterinarians and with the highest average values of animal export per public service veterinarian. The results documenting limited ability of public veterinary service to cope with animal population health represent a basis for future comparative studies in different territories.
\end{abstract}

Disease globalization, government veterinarians, public service crisis, public service workload, state service veterinarians, veterinary service

The availability of competent professional veterinary manpower in government services is of primary importance for the initiation and successful application of strategies, measures and methods to promote, protect and restore the health of animal populations and to protect human population health against zoonoses. Public veterinary service is irreplaceable driving force for effective transfer of scientific research results and of accumulated experience into animal population health practice at territorial, national and international levels. This paper tries to evaluate for the first time global government professional veterinary manpower situation using available data as reported by individual countries to international organizations. The global information system on professional veterinary manpower was established in 1983 within the framework of a joint venture between the Food and Agriculture Organization of the United Nations (FAO), the World Health Organization (WHO) and the International Office of Epizootics (OIE). They produced the FAO/WHO/OIE Animal Health Yearbook published by the FAO in Rome. In 1996, the OIE in Paris took over this role. First quantitative general analysis of global veterinary human resources, however, not considering individual countries, was published by Kouba (2003).

\section{Materials and Methods}

This study employed available data on government professional veterinary manpower published in relevant international yearbooks (FAO 1983-1995; OIE 1996-2004). For the first time global collecting and disseminating data on government professional veterinary manpower was introduced by Kouba (1983) when he was the Editor-in-Chief

Address for correspondence:

Prof. MVDr Václav Kouba, DrSc.

P.B. 516,17000 Praha 7

Czech Republic
Phone: +420233 381088

www. cbox.cz/vaclavkouba

http://www.vfu.cz/acta-vet/actavet.htm 
of the FAO/WHO/OIE Animal Health Yearbook and FAO Animal Health Officer (Veterinary Intelligence). He divided original reporting of "total number of veterinarians" into several categories including "government veterinary officials at central and local levels" (hereafter "public service veterinarians"). Simultaneously he introduced the collection of data on the number of private veterinarians, veterinarians in laboratories, universities and training institutions, of other veterinarians as well as of data on the number of technical personnel (animal health assistants, animal health auxiliaries and food hygiene technicians). Presented global analysis was complemented by examples from the selected countries to facilitate the comparison with other ones. Priority was given to main exporting countries having the major influence on international trade representing potential channel for animal disease export. For more detailed analysis 2000 and 2003 data were used according their availability. Not all countries sent relevant reports for all the years in consideration (examples see in Table 1). To obtain the most complete global data, the most recent reports available from those countries were used to substitute the missing information.

Table 1. Number of total, government and private veterinarians in the world as reported during 1983-2003

\begin{tabular}{|c|c|c|c|c|c|}
\hline \multirow{2}{*}{ Year } & \multirow{2}{*}{ Reports } & \multicolumn{2}{|c|}{ Reported number of veterinarians } & \multirow{2}{*}{ Missing major countries } \\
\cline { 2 - 5 } 1983 & & Total & Government & Private & \\
1984 & 116 & 240,404 & 659,30 & 79,026 & China (C), USSR (U) \\
1985 & 136 & 260,711 & 96,372 & 81,581 & C, U \\
1986 & 151 & 289,969 & 100,057 & 104,679 & C, U \\
1987 & 154 & 310,441 & 110,577 & 107,957 & C, U \\
1988 & 160 & 333,424 & 118,909 & 124,426 & C, U \\
1989 & 165 & 359,501 & 125,087 & 138,481 & C, U \\
1990 & 166 & 383,933 & 130,782 & 145,317 & C, U \\
1991 & 165 & 403,924 & 120,642 & 166,545 & C, U \\
1992 & 169 & 436,701 & 132,342 & 185,615 & C, U \\
1993 & 156 & 417,463 & 128,662 & 181,908 & C, Russia (R) \\
1994 & 135 & 552,331 & 144,888 & 228,697 & R, France \\
1995 & 110 & 520,263 & 141,317 & 215,676 & R \\
1996 & 132 & 565,500 & 154,126 & 229,956 & R \\
1997 & 140 & 524,342 & 151,529 & 206,761 & C, R \\
1998 & 152 & 527,074 & 125,173 & 219,692 & C, R \\
1999 & 145 & 530,626 & 153,995 & 226,699 & C, R \\
2000 & 128 & 490,668 & 156,344 & 212,286 & C, R, USA \\
2001 & 136 & 548,660 & 149,561 & 260,923 & C, R \\
2002 & 144 & 574,824 & 133,035 & 271,494 & C, R \\
2003 & 174 & 645,727 & 196,783 & 306,135 & 267,831 \\
\hline
\end{tabular}

For the calculation of relative values of some indicators FAO Statistical Databases (FAO 2002) was used as the source of data on farm animal populations, their production, land use, human populations, international trade in animals and animal products. Following indicators were selected:

- global growth of reported number of public service veterinarians, private veterinarians and total veterinarians during the period from 1983 to 2003 using differences in absolute and relative values, time series and the trend expressed by least squares regression line value;

- proportions of reported number in 2003 of public service veterinarians, private veterinarians, veterinarians working in diagnostic and research laboratories and in training/education institutions as well as of other veterinarians (working outside of veterinary service, retired, etc.); ratios between public service and private veterinarians;

- global averages per one public service veterinarian in the year 2000 using following criteria:

number of inhabitants, territory size, number of farm animals, number of livestock units (using following conversion rates: cattle $=0.7$; buffalo $=1$; horse $=1 ;$ mule $/$ ass; $=0.8 ;$ camel $=1.1 ;$ pig $=0.25 ;$ sheep 0.1 ; goat $=$ 0.1 ; chicken $=0.01$, number of slaughtered farm animals, size of livestock production, exported live animals (heads and monetary value) and exported animal products (weight and monetary value).

The analysis is complemented by identification of countries with the major number of public service veterinarians and by examples of public veterinary service professional staff reduction. For data processing software package EPIZOO, version 4.0 was employed (www.cbox.cz/vaclavkouba/software/software.zip). For the calculation of the livestock units was used EPIZOO subprogramme 11.11.7 b. 


\section{Results}

a) Total number of reported veterinarians increased during 1983-2003 period by $252 \%$ (from 240,404 to 605,306 ) while public service veterinarians only by $128 \%$ (from 65,930 to 150,429 ) and private veterinarians by $339 \%$ (from 79,036 to 267,831 ). Detailed time series see in Table 1 . The 1983-2003 trend of reported number of public service veterinarians expressed in time series regression line (least squares method) was $y=-7057007.5+3607.48 x$ with correlation coefficient $=0.8302$. The trend of reported number of private veterinarians expressed in time series regression line was $y=-20035214+10147.45 x$ with correlation coefficient $=0.9630$. Global growth of the number of public service veterinarians was relatively very slow when considering that much more intensive government supervision and much more rigorous preventive and disease control measures were required due to rapid increase of the trade in animals and animal products facilitating the spread and globalization of communicable diseases (Kouba 2003).

b) Global number of public service veterinarians reported by individual countries for the year 2003 (including the most recently available figures for those countries which did not submit actual reports) reached 209,888 (27.96\% of all reported veterinarians in the world). The reported number of veterinarians employed at laboratories, universities and training institutions was $77,439(10.32 \%)$ and the reported number of veterinarians in private service reached 374,645 $(49.90 \%)$, see Table 2 . Reported number of public service veterinarians in selected countries significantly influencing the global values see in Table 3. Among the countries with highest reported number belonged China - 43,900, India - 31,495 and Egypt - 19,750.

Table 2. Global number of veterinarians in public service, private service and laboratories/universities and training institutions as reported in 2003, eventually in previous years

\begin{tabular}{|lcccc|}
\hline Category & Number reported in 2003 & $\%$ & Number reported in 2003 & $\%$ \\
\hline Public service & 150,429 & 24.85 & 209,888 & 27.96 \\
Private service & 267,831 & 44.25 & 374,645 & 49.90 \\
Labor./training & 62,309 & 10.29 & 77,439 & 10.32 \\
Others & 124,737 & 20.61 & 88,727 & 11.82 \\
\hline Total & 605,306 & 100.00 & 750,699 & 100.00 \\
\hline
\end{tabular}

Table 3. Order list of the countries with major number of public service veterinarians as reported in 2003, eventually in previous years

\begin{tabular}{|rccccc|}
\hline Order & Country & Number & $\begin{array}{c}\text { \% of all public } \\
\text { vet. in world }\end{array}$ & $\begin{array}{c}\text { Ratio } \\
\text { public/total }\end{array}$ & $\begin{array}{r}\text { Ratio } \\
\text { public/private }\end{array}$ \\
\hline 1 & China & 43,900 & 20.92 & 0.3859 & 0.8767 \\
2 & India & 31,495 & 15.01 & 0.8266 & 15.9468 \\
3 & Egypt & 19,750 & 9.41 & 0.4759 & 1.5800 \\
4 & Japan & 8,106 & 3.85 & 0.2638 & 0.4804 \\
5 & Ukraine & 6,967 & 3.32 & 0.5453 & 4.3763 \\
6 & Italy & 5,648 & 2.69 & 0.3179 & 0.5888 \\
7 & Cuba & 5,363 & 2.56 & 0.8099 & \\
8 & Kazakhstan & 3,737 & 1.78 & 0.4109 & 0.6976 \\
9 & Brazil & 2,867 & 1.37 & 0.0540 & 0.0636 \\
10 & USA & 2,782 & 1.33 & 0.0479 & 0.0618 \\
\hline
\end{tabular}

Note: Data from Russia not available.

c) Global ratios between numbers of public service veterinarians and private veterinarians reported in 2003 reached following values: ratio public/private veterinarians $=0.5602$ and ratio private/public veterinarians $=1.7850$. Ratio public/total veterinarians $=0.2796$ and 
ratio total/public veterinarians $=3.5769$. Ratio of public veterinarians to veterinarians in laboratories, universities and training institutions reached 2.7104 and inverse ratio was 0.3690 . Among the countries with the major value of ratio private/public veterinarians belonged: Bulgaria - 17.3636, USA - 16.1787 and Australia - 11.9492. More examples see in Table 4.

Table 4. Order list of the countries with the highest value of the ratio private/public veterinarians in 2003

\begin{tabular}{|rlcccrc|}
\hline Order & Country & $\begin{array}{c}\text { Number of public } \\
\text { veterinarians }\end{array}$ & $\begin{array}{c}\text { \% of all public } \\
\text { vet. in world }\end{array}$ & $\begin{array}{c}\text { Number of private } \\
\text { veterinarian }\end{array}$ & $\begin{array}{c}\text { \% of all private } \\
\text { vet. in world }\end{array}$ & $\begin{array}{c}\text { Ratio } \\
\text { private/public }\end{array}$ \\
\hline 1 & Bulgaria & 99 & 0.047 & 1,719 & 0.4588 & 17.3636 \\
2 & USA & 2,782 & 1.325 & 45,009 & 12.0138 & 16.1787 \\
3 & Australia & 512 & 0.244 & 6,118 & 1.6330 & 11.9492 \\
4 & Canada & 664 & 0.316 & 7,167 & 1.9130 & 10.7937 \\
5 & Unit. Kingdom & 923 & 0.440 & 9,945 & 2.6545 & 10.7747 \\
6 & France & 1,221 & 0.582 & 12,933 & 3.4521 & 10.5921 \\
7 & Switzerland & 165 & 0.079 & 1,400 & 0.3737 & 8.4848 \\
8 & Austria & 238 & 0.113 & 1,938 & 0.5173 & 8.1428 \\
9 & Netherlands & 458 & 0.218 & 3,049 & 0.8138 & 6.6572 \\
10 & New Zealand & 227 & 0.108 & 1,198 & 0.3198 & 5.2775 \\
\hline
\end{tabular}

d) Global average numbers of inhabitants and size of land area per one public service veterinarian in the year 2000 were as follows: 31,522 inhabitants; 13,368 people depending for their livelihood on agriculture; 6,867 people economically active in agriculture; $680 \mathrm{~km}^{2}$ of land; $71 \mathrm{~km}^{2}$ of arable land suitable for crop production and $7 \mathrm{~km}^{2}$ of land under permanent crop cultivation.

e) Global average numbers of animals per one public service veterinarian in the year 2000 were as follows: 6,932 cattle, 870 buffaloes, 313 horses, 5,421 sheep, 3,719 goats, 4,711 pigs and 74,581 chickens. Global average number of livestock units per one public service veterinarian was 9,221. Among the countries with the highest average number of livestock units per one public service veterinarian belonged Australia $(63,121)$, New Zealand $(57,244)$ and USA $(46,886)$. For more information see Table 5.

Table 5. Average values of annual animal export, animal populations and livestock units per one public service veterinarian in the major exporting countries, 2000

\begin{tabular}{|c|c|c|c|c|c|c|c|c|}
\hline \multirow[t]{2}{*}{ Country } & \multicolumn{4}{|c|}{ Export values in USD } & \multicolumn{3}{|c|}{ Populations } & \multirow{2}{*}{$\begin{array}{c}\text { Livestock } \\
\text { units }\end{array}$} \\
\hline & Total & Animals & Meat & Milk & cattle & sheep & pigs & \\
\hline N. Zealand & $14,783,812$ & 29,349 & $8,961,854$ & $5,792,609$ & 43,872 & 216,798 & 6,631 & 57,244 \\
\hline Netherlands & $14,480,214$ & 863,115 & $10,344,361$ & $3,272,738$ & 11,465 & 3,683 & 36,952 & 21,024 \\
\hline Australia & $8,285,069$ & 797,134 & $5,786,006$ & $1,701,929$ & 55,422 & 227,724 & 5,179 & 63,121 \\
\hline Denmark & $7,372,482$ & 273,308 & $6,476,711$ & 622,463 & 3,648 & 284 & 23,284 & 8,907 \\
\hline France & $6,207,885$ & $1,281,685$ & $3,360,102$ & $1,566,098$ & 20,097 & 9,509 & 15,993 & 22,889 \\
\hline Ireland & $5,933,074$ & 984,526 & $3,730,654$ & $1,217,844$ & 19,707 & 20,811 & 4,892 & 17,669 \\
\hline Canada & $5,535,061$ & $1,573,773$ & $3,821,330$ & 139,958 & 21,556 & 1,263 & 17,888 & 22,140 \\
\hline USA & $3,728,074$ & 173,688 & $3,369,462$ & 184,924 & 43,438 & 3,089 & 26,696 & 46,886 \\
\hline U.Kingdom & $2,128,801$ & 148,567 & $1,235,647$ & 745,587 & 11,179 & 38,657 & 8,180 & 16,932 \\
\hline Germany & $1,776,298$ & 154,777 & 758,460 & 863,061 & 5,199 & 985 & 9,255 & 6,614 \\
\hline
\end{tabular}

f) Global average numbers of animals slaughtered in abattoirs during the year 2000 per one public service veterinarian were as follows: 1,445 cattle, 2,517 sheep, 1,024 goats and 6,026 pigs. Among the countries with the highest average number of slaughtered farm 
animals per one public service veterinarians belonged New Zealand (17,210 cattle, 160,144 sheep and 3,779 pigs $=181,133$ animals), Australia (17,059 cattle, 62,203 sheep and 9,890 pigs $=93,152$ animals $),$ USA (16,780 cattle, 1,575 sheep and 43,797 pigs $=62,152$ animals $)$, Netherlands (6,330 cattle, 2,140 sheep and 52,292 pigs $=60,763$ animals $)$ and South African Republic (10,739 cattle, 42,450 sheep and 7,202 pigs $=60,391$ animals).

g) Global average volume of livestock production during the year 2000 per one public service veterinarian was as follows: 1,211 tonnes $(\mathrm{t})$ of total meat, $295 \mathrm{t}$ beef/veal, 40 $\mathrm{t}$ mutton/lamb, $20 \mathrm{t}$ goat meat, $467 \mathrm{t}$ pig meat, $230 \mathrm{t}$ poultry meat, 2,551 t cow milk and 267 t hen eggs. Among the countries with the highest average of produced meat per one public service veterinarian belonged USA (15,952 t), Netherlands (7,930 t), Australia (7,085 t), New Zealand $(6,776 \mathrm{t})$ and Canada $(5,639 \mathrm{t})$.

h) Global average number and monetary value of internationally traded live animals during the year 2000 per one public service veterinarians were as follows: 43 cattle (US\$ 21,617), 83 sheep (US\$ 4,126), 80 pigs (US\$ 6,638), 2 horses (US\$ 9,226) and 3,910 chickens (US\$ 4,029). Among the countries with the highest average monetary value of exported animals per one public service veterinarian belonged Canada (US\$ 1,573,733), France (US\$ 1,281,685) and Australia (US\$ 797,134).

i) Global average volume and monetary value of internationally traded animal products during the year 2000 per one public service veterinarian were as follows: $120 \mathrm{t}$ total meat and meat products (US\$ 232,819), $10 \mathrm{t}$ beef/veal (US\$ 20,028), $5 \mathrm{t}$ mutton/lamb (US\$ $11,286), 12$ t pork (US\$ 18,638) and $31 \mathrm{t}$ chicken meat (US\$ 31,609). Among the countries with the highest average monetary value of exported meat per one public service veterinarian belonged Netherlands (US\$ 10,344,361), New Zealand (US\$ 8,961,854), Denmark (US\$ 6,476,711) and Australia (US\$ 5,786,006).

j) Countries where monetary value of exported animals and animal products in 2000 was higher than one million US\$ per one public service veterinarian: New Zealand - 14,783,812; Netherlands - 14,480,214; Australia - 8,285,069; Denmark - 7,372,482; France 6,207,885; Canada - 5,535,061; USA - 3,728,074; United Kingdom - 2,128,801 and Germany - 1,776,298 (see Table 5).

k) Comparative analyses of data between different years demonstrated that in many countries public service professional veterinary staff was reduced. Examples: Australia (1989 - 821; 2003 - 512), Brazil (2001 - 15,260; 2003 - 2,867), Canada (1984 - 1080; 2003 - 664), Indonesia (1998 - 2,675; 2003 - 735), Kenya (1996 - 1,053; 2003 - 531), Spain $(2000-6,936 ; 2003-2,248)$ and USA (1995-4,323; $2003-2,782)$.

\section{Discussion}

Not all reported data were complete and systematically updated. Therefore, the results have to be understood as estimates, however, closely approximate to the reality. The paper is dedicated to global aspects complemented by examples from selected countries. The average values of selected indicators reflect, to a certain extent, the workload and responsibility of government veterinary officials and their ability to cope with particular animal health tasks and problems. The role of these professionals is to protect the interests of the whole society that are different from profit-oriented private veterinarians.

Due to the fact that this kind of global analysis is historically the first one, it could not be compared with any similar analysis in previous literature available. On the other hand, there were many papers published dealing only with local analyses of public veterinary services. In this context OIE 2003 compendia can be mentioned, one on veterinary service organization and one on veterinary institutions, papers of Ozawa et al. (2003) providing 
examples from developed countries and Rweyemamu and Astudillo (2003) commenting on the situation in developing world. These publications indirectly support the results of presented analysis confirming a critical shortage of professional veterinary manpower in public services. Without sufficient number of government veterinary officials the national veterinary services cannot cope effectively with health protection of the animal population, disease surveillance, control, reduction and eradication as well as with national and international trade to avoid pathogens spreading. Weak public service, when comparing average values of relevant indicators per one public service veterinarian, is logically unable to cope adequately with its animal health problems and to supervise effectively all accredited private veterinarians and laboratories. Without systematic control of accredited veterinarians and laboratories cannot be expected consistent and reliable implementation of their activities on behalf of government (e.g. issuing health guaranteing documents for export). In many countries, instead of strengthening public veterinary services, the number of their professionals was reduced in spite of steadily increasing needs, size and complexity of the problems related to animal health programmes, food hygiene and rapidly developing national and international animal trade. Not always independent and trustworthy private accredited veterinarians cannot fully replace public service in carrying out all multiplex duties on behalf of the government (Griffiths and Konigshofer 1974; FAO 1991). Of particular concern are relatively very weak public veterinary services in some exporting countries being unable to control effectively the trade and to guarantee the export of only healthy animals and pathogen-free animal products and thus to avoid international disease spread. The analysis documents critical situation in public veterinary service facilitating the globalization of communicable diseases due to their spreading through insufficiently controlled international trade (Kouba 2003). Territorial, national and international animal health programmes and the applications of research results cannot be successfully carried out at animal population level without necessary number of properly managed competent public service veterinarians.

It is difficult to perform any objective comparison among the individual countries. The quantitative criteria without consideration of qualitative aspects cannot fully reflect the ability of public veterinary service to cope with their problems. For this purpose also many different aspects should be taken into account, such as: animal and human disease situation and programmes; public health, economic, ecologic, trade and social conditions; public veterinary service development, its staff size and structure, workload (incl. proportions of field and administrative activities), diagnostic and other facilities, material, financial and legal support, management and organization; size and structure of national and international trade in animals and their products, etc.

The results of this analysis can provide a departure basis for comparative studies when assessing the trend and ability of public veterinary services to cope with animal health problems, when planning future veterinary manpower development and for identifying future educational and research needs. Using the year 2000 as the turning point between decades and centuries will facilitate these studies.

Note: More information in www.cbox.cz/vaclavkouba/vetmanpower.htm.

\section{Globální kvantitativní analýza veterinárních lékařů ve státní službě}

Historicky první globální analýza počtu veterinárních lékařů ve státní službě vychází z dostupných kvantitativních údajů hlášených jednotlivými zeměmi mezinárodním organizacím. Analýza začíná časovou sérii hlášených počtů veterinárních lékařů státní služby počínaje rokem 1983 (65,930). V roce 2003 tento počet dosáhl 209,888 reprezentující $27.96 \%$ z počtu všech hlášených veterinárních lékařù ve světě. Poměr soukromých ke státním veterinárním lékařům dosáhl 1.7850 a poměr státních k soukromým veterinárním 
lékařům 0.5602 . Globální průměrné hodnoty na jednoho veterinárního lékaře státní služby v roce 2000 byly následující: 31,522 obyvatel, 13,368 osob existenčně závislých na zemědělství a 6,867 osob pracujících v zemědělství; $680 \mathrm{~km}^{2}$ území a $71 \mathrm{~km}^{2}$ orné půdy; 6,923 kusů skotu, 870 buvolů, 313 koní, 5,421 ovcí, 3,719 koz, 4,711 prasat a 74,581 kusů domácí hrabavé drůbeže; poraženo 1,445 kusů skotu, 2,517 ovcí, 1,024 koz a 6,026 prasat; vyprodukováno 1,211 tun masa, 2,551 tun kravského mléka a 267 tun drůbežích vajec; mezinárodně obchodováno s 43 kusy skotu, 83 ovcí, 80 prasat a 3,910 drůbeže a 120 tuny masa. Analýza je doplněna příklady zemí s nejvyššími počty státních veterinárních lékařư, s nejvyšším poměrem soukromých ke státním veterinárním lékařům a s nejvyššími průměrnými hodnotami animálního exportu na jednoho státního veterinárního lékaře. Výsledky dokumentující omezenou schopnost státní veterinární služby zvládat zdraví populací zvirirat představují východisko $\mathrm{k}$ budoucím komparativním studiím.

\section{References}

FAO 1956-1995: FAO/WHO/OIE Animal Health Yearbook. FAO, Rome.

FAO 1991: Guidelines for strengthening animal health services in developing countries. FAO, Rome, $141 \mathrm{p}$.

FAO 2002: Statistical Databases (FAOSTAT). FAO, Rome. (http://apps.fao.org/ - accessed 22 October 2003)

GRIFFITHS RB, KONIGHOFER H O 1974: Standard of Veterinary Services, FAO, Rome, 16 p.

KOUBA V (Editor) 1983: FAO/WHO/OIE Animal Health Yearbook, FAO, Rome, 208 p.

KOUBA V 2003: Globalization of Communicable Diseases of Animals - A Crisis of Veterinary Medicine. Acta Vet. Brno 72: 453-460 (www.vfu.cz/acta-vet/vol72/453-03.htm).

KOUBA V 2003: Quantitative analysis of global veterinary human resources. Rev. sci. tech. Off. Int. Epiz., 2003, 22 (3): 899-908 (www.oie.int/eng/publicat/RT/2203/A_R22311.htm).

OIE 1996-2004: World Animal Health (yearbook). OIE, Paris.

OIE 2003: Veterinary Services: organization, quality assurance, evaluation. Rev sci tech Off int Epiz 22(2), 309 p.

OIE 2003: Veterinary institutions in the developing world: current status and future needs. Rev sci tech Off int Epiz 23 (1), $401 \mathrm{p}$.

OZAWA Y, CHANG K, YOSHIDA K, MICHINO H 2003: The present and future organization of Veterinary Services in Asia: the examples of the Republic of Korea and Japan. Rev sci tech Off int Epiz 22(2): 499-508

RWEYEMAMU MM, ASTUDILLO VM 2003: Global perspectives for foot and mouth disease control. Rev sci tech Off int Epiz 21 (3): 765-773 